Gerontologia 1970;16:I-IV

\title{
Contents, Vol. 16, 1970
}

\section{Gerontologia}

Journal of Experimental Biological and Experimental Medical

Research on Ageing - Zeitschrift für experimentell-biologische und -medizinische Alternsforschung - Journal de Recherches expérimentales, biologiques et médicales, sur le vieillissement

Editor F. Verzár, Basel

\section{Coeditores}

F. Bourlière, Paris D. A. Hall, Leeds

N. W. Shock, Baltimore, Md. H. P. von Hahn, Basel

Collaboratores

A. v. Albertini, Zurich

P. Alexander, London

W. Andrew, Indianapolis, Ind.

J. Baló, Budapest

J. Banga, Budapest

J. E. Birren, Los Angeles, Calif.

G. H. Bourne, Atlanta, Ga.

A. Comfort, London

J. Danielli, Buffalo, N.Y.

W. Doberauer, Wien

G. Di Macco, Roma

A. V. Everitt, Sydney

A. Fleckenstein, Freiburg i. Br.

S. M. Friedman, Vancouver

T. Geill, København

T. Gillman, Cambridge

J. Groen, Jerusalem

H. Guth, Basel

L. Haranghy, Budapest

W. J. E. Jessop, Dublin

V. R. Khanolkar, Bombay

P. S. Krishnan, Lucknow

P. L. Krohn, Birmingham

P. J. Lindop, London

K. Miescher, Basel

H. Mislin, Mainz

O. Mühlbock, Amsterdam

R. Nicolaysen, Oslo

F. Roulet, Basel 
. H. Sheldon, Wolverhampton

F. M. Sinex, Boston, Mass.

R. E. Tunbridge, Leeds

A. L. Visgher, Basel

R. Wagner, München

A. Welford, Cambridge

1970

Vol. 16

S. Karger · Basel (Switzerland) · München · New York

Index

Ákos, K. and Ákos, M.: Age Changes in Men of Critical Flicker Frequency Series

Effect (CFFSE) 41

Ákos, M.: vide Ákos, K.

Árvay, A.: vide Balogh, Ä.

Balogh, Á.; Takács, I.; Ladányi, P., and Árvay, A.: Electron Microscopic Studies

of the Adenohypophyses of Aged Rats

313

Bartos, Fr. : Aging of Collagen in Tissue Culture 212

Beneke, G.; Feigel, H. W. und Mohr, W.: Die Reaktion des parietalen Peritone-

ums der Ratte in Abhängigkeit vom Lebensalter 283

Beneke, G.: vide Schmitt, W.

Beregi, Edith: Comparative Morphological Studies of the Allergic Reactions of

Young and Old Animals 141

Bezrukov, V. V.: vide Frolkis, V. V.

Bogatskaya, L. N.: vide Frolkis, V. V.

Bojanovic, J.J.; Jevtovic, A. D.; Pantic, V. S.; Dugandzic, S. M., and Jovanovic, D. S.: Thymus Nucleoproteins. Thymus Histones in Young and Adult

Rats 304

Broek, C. van den: vide Simons, J. W. I. M.

Burcombe, Judith V. and Hollingsworth, M.J.: The Relationship between

Developmental Temperature and Longevity in Drosophila 172

Coggle, J. E. and Proukakis, C.: The Effect of Age on the Bone Marrow Cellularity of the Mouse 25

Comfort, A.: Basic Research in Gerontology 48

Denkhaus, W. und Heimer, D.: Mikrofluorometrische Bestimmung der «freien DNS-P04-Gruppen» im Chromatin nativer Leberzellkerne von jungen und alten Meerschweinchen 1

Dowling, L. E.: vide Russell, A. P.

Dugandzic, S. M.: vide Bojanovic, J.J.

Ermini, M.: Das Altern der Skelettmuskulatur. Die Restitution des Kreatinphos-

phates der Skelettmuskulatur nach Arbeit bei Ratten verschiedenen Alters 65 Ermini, M.: Das Altern der Skelettmuskulatur. Untersuchungen an der Myofibril-

len-Adenosin-5'-Triphosphatase bei verschieden alten Ratten 72

Ermini, M.: Das Altern der Skelettmuskulatur. Kreatinkinase in der Muskulatur verschieden alter Ratten 231

Index 
III

Ermini, M.: vide Verzár, F. Ervig, K.: vide Schmitt, W. Everitt, A. V.; Gal, A., and Steele, M. G.: Age Changes in the Solubility of Tail

Tendon Collagen Throughout the Lifespan of the Rat 30

Everitt, A. V.: vide Steele, M. G.

Feigel, H. W.: vide Beneke, G.

Frolkis, V. V.; Bezrukov, V. V.; Bogatskaya, L. N.; Verkhratskv, N. S.;

Zamostian, V. P.; Shevtchuk, V. G., and Shtchegoleva, I. V.: Cate-

cholamines in the Metabolism and Functions Regulation in Aging .... 129 Fukunaga, Y.: vide Inoue, G. Gal, A.: vide Everitt, A. V. Hahn, H. P. von: Structural and Functional Changes in Nucleoprotein During the

Ageing of the Cell. Critical Review 116

Hall, D. A.: Coordinately Bound Calcium as a Cross Linking Agent in Elastin and as an Activator of Elastolysis 325

Heimer, D.: vide Denkhaus, W. Herrmann, R. L.: vide Russell, A. P.

Hollingsworth, M. J.: The Threshold Theory of Ageing 252

Hollingsworth, M. J.: vide Burcombe, Judith V.

Inoue, G.; Sawada, T.; Fukunaga, Y., and Yoshikawa, M.: Levels of Acid Muco-

polysaccharides in Aging Human Kidneys 261

Jevtovic, A. D.: vide Bojanovió, J. J.

Jovanovic, D. S.: vide Bojanoגíc, J. J.

Kerber, S.: vide Lewi, S.

Ladányi, P.: vide Balogh, Á

Larking, P.: vide Nye, E. R.

Lewi, S. et Kerber, S.: Transformation lymphoblastique in vitro et reaction cutanée à la Phytohémagglutinine chez les personnes âgées $\quad 14$

Miwa, T.: vide Sato, T.

Mohr, W.: vide Beneke, G.

Naylor, G. J.: The Relationship between Age and Sodium Metabolism in Human

Erythrocytes 217

Nye, E. R. and Larking, P.: Effect of Diet on Blood and Tissue Lipid Levels in

Aged Male Rats 266

Pantic, V. S.: vide Bojanovic, J. J.

Patnaik, B. K.: Studies on Collagen as a Template for Calcium Apatite 96

Patnaik, B. K.: vide Verzár, F.

Peereboom, J. W. Copius: Age-dependent Changes in the Human Intervertebral

Disc. Fluorescent Substances and Amino Acids in the Anulus Fibrosus . . 352 Proukakis, C.:

vide Coggle, J. E. Rowlatt, C.: Some Effects of Age and Castration in the Epithelial Basal

Lamina of

Secondary Sex Organs in the Mouse 182

Russell, A. P.; Dowling, L. E., and Herrmann, R. L.: Age-Related Differences in

Mouse Liver DNA Melting and Hydroxylapatite Fractionation 159

Sato, T.; Miwa, T., and Tauchi, H.: Age Changes in the Human Liver of the

Different Races $\quad 368$

Sawada, T.: vide Inoue, G.

Schlettwein-Gsell, Daniela : Survival Curves of an Old Age Rat Colony ... Ill 
Schmitt, W.; Ervig, K. und Beneke, G.: Altersabhängige Veränderungen der Achillessehne des Kaninchens 238

Shevtchuk, V. G.: vide Frolkis, V. V. Shtchegoleva, I. V.: vide Frolkis, V. V.

IV

Index

Silberberg, M. and Silberberg, Ruth : Age-Linked Modification of the Effect of

Estrogen on Joints and Cortical Bone of Female Mice 201

Silberberg, Ruth: vide Silberberg, M.

Simons, J. W. I. M. and Broek, C. van den: Comparison of Ageing in vitro and

Ageing in vivo by Means of Cell Size Analysis Using a Coulter Counter . 340 Spichtin, H.: Age Changes of Dry Weight and Collagen Content of the Skeleton of

the Rat 104

Steele, M. G. and Everitt, A. V.: Age Changes in the Subunit Composition of Rat

Tail Tendon Collagen Extracted at $65^{\circ} \mathrm{C}$ in Water and at $2^{\circ} \mathrm{C}$ in Acid ... 277 Steele, M. G.: vide Everitt, A. V. Takács, I.: vide Balogh, Á. Tauchi, H.: vide Sato, T. Verkhratsky, N. S.: vide

Frolkis, V. V. Verzár, F. and Ermini, M.: Decrease of Creatine-phosphate Restitution of Muscle in Old Age and the Influence of Glucose 223

Verzár, F. and Patnaik, B. K.: Ageing-Like Changes of Collagen Fibers During

Storage in vitro 83

Verzár, F. and Zs.-Nagy, I.: Electronmicroscopic Analysis of Thermal Collagen

Denaturation in Rat Tail Tendons 77

Yoshikawa, M.: vide Inoue, G. Zamostian, V. P.: vide Frolkis, V. V. Zs.-Nagy, I.: vide Verzár, F.

In memoriam. Enrico Greppi 197

In memoriam. Martin Silberberg 199

Book Reviews - Buchbesprechungen - Livres nouveaux 259, 324, 381

Varia 260, 382

Index rerum vol. $16 \quad 383$

S. Karger AG, Arnold-Böcklin-Strasse 25, CH-4000 Basel 11 (Switzerland)

All rights, including that of translation into other languages, reserved.

Photomechanic reproduction (photocopy, microcopy) of this volume or parts thereof without special permission of the publishers is prohibited.

(C)

Copyright 1970 by S. Karger AG, Verlag für Medizin und Naturwissenschaften, Basel Printed in Switzerland by Buchdruckerei National-Zeitung AG, Basel 